\title{
İshalli hastalarda direkt fluoresan antikor-DFA yöntemi ile Giardia ve Cryptosporidium spp. araştırılması
}

\section{Investigation of Cryptosporidium spp. and Giardia by direct fluorescent antibody-DFA method in stool specimens obtained from patients with diarrhea}

\author{
Semra Özçelik*, Serpil Değerli, Dilara Yıldırım \\ Parazitoloji Anabilim Dalı (Prof. Dr. S. Özçelik, Prof. Dr. S. Değerli), Cumhuriyet Üniversitesi \\ Tıp Fakültesi, TR-58140 Sivas, Mikrobiyoloji Laboratuvarı (Dr. D. Yıldırım), Sivas Numune \\ Hastanesi, TR-58100 Sivas
}

\begin{abstract}
Özet
Amaç. Cryptosporidium spp. ve Giardia intestinalis insanda ishal nedeni olabilen önemli protozoonlardır. Bu parazitozların tanısında etkensel tanı yöntemlerinin yanında antijen tarama testleri de kullanılabilmektedir. Çalışmamızda ishalli hastalarda konvansiyonel yöntemlerle birlikte Direkt Fluoresan Antikor (DFA) yöntemi ile G.intestinalis ve Cryptosporidium spp. varlığının saptanması ve bu iki protozoonun gastroenterit olgularındaki rolünün araştırılması amaçlanmıștır. Yöntem. Sivas il merkezindeki üç hastanenin (Cumhuriyet Üniversitesi Uygulama ve Araştırma Hastanesi, Sivas Numune ve Sivas Devlet Hastanesi) çeşitli servislerine enterit yakınmalarıyla başvuran 32'si kadın, 68'i erkek toplam 100 ishalli hastaya ait dışk örneklerinde direkt inceleme ve asit-fast boyama yöntemi ile yapılan mikroskobik incelemelerde parazitlere ait kist ve/veya ookistler, DFA yöntemi ile parazitlere ait antijenler araştııılmıştır. İncelenen grupta yer alan hastalar 0-80 yaş aralığında bulunmaktadır. Bulgular. Çalışmada, ishalli 100 dışkı örneğinin 2'sinde direkt mikroskobide G.intestinalis görülmüştür. Asit-fast boyama ile birinde Cryptosporidium spp. görülürken, DFA ile 4'ünde (\%4,0) Cryptosporidium spp., 2'sinde $(\% 2,0)$ G. intestinalis antijenlerine rastlanmıștır. Cryptosporidium spp. saptanan hastaların erişkin yaş grubunda yer alması ilginç bulunmuştur. Sonuç. Cryptosporidium spp. ve G. intestinalis'in ikisini de içeren DFA testleri rutin çalışmalarda ve prevalans araştırmalarında kullanılabilen kolay, duyarlı ve güvenilir bir testtir. Diğer taraftan enterit nedenleri arasında sayılan bu iki protozoon incelenen hasta grubunda toplam \%6 oranında bulunmuştur.
\end{abstract}

Anahtar sözcükler: Cryptosporidium spp., giardia intestinalis, DFA, ishal

\begin{abstract}
Aim. Cryptosporidium spp. and Giardia intestinalis are important parasitic protozoan causing diarrhea in developing and developed countries. Diagnosis of the Cryptosporidium oocyst in stool samples by conventional microscopy is labor-intensive and time-consuming. Thus, we aimed the presence of these protozoa in patients with diarrhea and to evaluate the usefulness of direct fluoresan antibody (DFA) test in detecting Cryptosporidium spp and G.intestinalis. from fecal specimens. Methods. For this aim, microscopy and specific antigen detection methods were used to determine Cryptosporidium spp. and G.intestinalis. One hundred stool specimens were examined taken from patients with diarrhea whose ages ranged from 0 to 80 of applied to Hospital of Cumhuriyet University, Numune and Goverment Hospital in Sivas. All samples were tested for Cryptosporidium spp. G.intestinalis antigen by DFA and oocysts via gold Standard modified acidfast staining for Cryptosporidium spp.and G.intestinalis direct microscopy. Results. One specimen was found to be positive by modified acid-fast staining method and four specimens by DFA method were found to be positive for cryptosporidiosis. On the other hand two specimens were found to be positive both direct microscopy and DFA for giardiosis. Conclusion. The results of DFA test indicate that the simple, rapid, reliable, and standardized test is sensitive and specific for routine diagnosis and may be useful for large-scale epidemiological studies of cryptosporidiosis and giardiosis.
\end{abstract}

Keywords: Cryptosporidium spp., giardia intestinalis, DFA, diarrhea 
Geliş tarihi/Received: 14 Ekim 2014; Kabul tarihi/Accepted: 08 Aralık 2014

\section{*iletişim adresi:}

Dr. Semra Özçelik, Parazitoloji Anabilim Dalı, Cumhuriyet Üniversitesi Tıp Fakültesi, TR-58140 Sivas. E-posta: ozceliksemra@yahoo.com

\section{Giriş}

Cryptosporidiosis farklı genotipteki Cryptosporidium spp.'lerin insan ve hayvanlarda asemptomatik infeksiyondan akut enterik hastalıklara kadar değişebilen tablolara yol açtığı bilinen bir hastalıktır [1]. İnsanlarda 1982 yılına kadar daha çok bağışıklık sistemi baskılanmış bireylerin infeksiyonu olarak bilinen cryptosporidiosisin özellikle laboratuvar tanı yöntemlerinin gelişmesiyle bağışıklık sistemi sağlam bireylerde de görülebileceği ve hastalık oluşturabileceği belirlenmiştir [2, 3]. Cryptosporidium spp. insandan insana direkt temasla, su veya besin yoluyla, hayvanlarla temas yoluyla, hava yoluyla, toprak ve taşıyıcı konaklarla, indirekt yolla ve seksüel yolla bulaşabilir [2]. Cryptospordium enfeksiyonu ilk defa 1907 yılında Tyzzer tarafından farelerde gösterilerek tanımlanmıştır. 1980 lerde AIDS li hastalarda ölüme yol açan zoonotik bir hastalığın etkeni olduğu araştırıcılar tarafından rapor edilmiştir [1-3]; 1990 larda özellikle Amerika Birleşik Devletleri'nde salgınlar oluşturduğu ve sağlam bireylerde de hastalık yapabildiği bildirilmiştir. Ayrıca aynı dönemlerde seyahat ishallerinden sorumlu olduğu belirlenmiştir $[4,5]$.

Araştırmalarda farklı yöntemler kullanılmış olsa da geri kalmış ülkelerde, 2 yaş altı çocuklarda [6-8], evcil hayvan besleyenlerde [9], gastroenteritlilerde [10, 11], beslenme yetersizliklerinde [11), homoseksüellerde, immünyetersiz bireylerde, seyahat edenlerde, sıcak ve nemli ortam ve mevsimlerde enfeksiyonun daha sık görüldüğ̈̈ bildirilmektedir [2]. Bu çalışmaların bazılarında Cryptosporidium ookistlerinin klorlanmış sularla veya herhangi bir işleme tabi tutulmayan sularla enfeksiyona neden olabileceği belirlenmiştir. Ayrıca infekte insan ve hayvan dışkılarıyla kontamine olmuş havuzlar ve göllerin birer kaynak olabileceği saptanmıştır [12-15].

Cryptosporidiidae ailesine bağl1 22 Cryptosporidium türü adlandırılmıştır. C. parvum türü ise bazı memeli hayvanlardan ve insandan (genotip 2) bildirilen en yaygın türdür ve 7 farklı genotipinin bulunduğu bildirilmiştir. Zoonoz karekterdeki C. parvum ile anthroponotik karekterdeki C. hominis insandaki cryptosporidiosisden en sik sorumlu olan etkenlerdir [16].

G. intestinalis, enterik bir protozoon olup, sanayileşmiş ve gelişmiş ülkelerde ishal, malabsorpsiyon ve gelişme geriliği nedeni olarak bilinmektedir. Gelişmekte olan ülkelerde asemptomatik infeksiyonlar daha yaygındır ve diyare nedeni olmaları soru işaretiyle karşılanmaktadır. Gelişmiş ülkelerde ise ishal nedeni olmakla birlikte infeksiyona genel popülasyonda \%5 civarında rastlanmaktadır. Çocuklarda ise bu oran \%30'lara kadar çıkabilmektedir. Çocuklarda malabsorpsiyonun eşlik ettiği, akut ve persistan diyareye neden olduğunu belirten yayınlar da, akut diyareyle ilişkisi olmadığını belirten çalı̧̧malar da bulunmaktadır. Deneysel çalışmalarla G.intestinalis'in bazı suşlarının gönüllü sağlıklı bireylerde diareye neden olduğu gösterilmiştir [17].

G.intestinalis'in infekte bireylerde tanısı, dışkı incelemelerinde mikroskobik olarak, parazitin kist ve/veya trofozoitlerinin görülmesiyle konmaktadır. Kist sayısının az olduğu durumlarda ise bulunamayabilir. Bu ve benzer nedenlerle günümüzde dışkıda antijen arayan ELISA (duyarlılık \%90-100, özgüllük \%100) ve Direkt Fluoresan Antikor testi (DFA) (duyarlılık ve özgüllük her ikisi de \%100) de tanıda kullanılmaktadır [18].

$\mathrm{Bu}$ çalışmadaki amacımız, gastroenterit tanısı alan kişilerde G. intestinalis ve Cryptosporidium spp. nin prevalansını DFA yöntemiyle saptamak ve ishalli olgularda bu iki protozoonun rolünü belirlemeye çalışmaktır. 


\section{Gereç ve yöntem}

Çalışmada, Nisan 2012 ile Eylül 2012 tarihleri arasında Cumhuriyet Üniversitesi Uygulama ve Araştırma Hastanesi, Sivas Numune ve Devlet Hastanelerine başvuran 100 ishalli hastanın dışkıları incelenmiştir. Hastaların 24'ü 0-16 arası çocuk yaş grubunda yer alırken, 66's1 17 yaş ve üzerinde bulunmaktaydı.

Dışkı örneklerinin toplanması: Dışkı örnekleri yukarıda belirtilen tarihler arasında toplanmıştır. Dışkı örneği toplanacak kişiler çalışma ile ilgili olarak bilgilendirilmiş ve onayları alındıktan sonra dışkıları toplanmıştır. Dışkılar su çekmeyen dışkı kaplarına alınmış, kutu üzerindeki etiketlere gerekli açıklamalar yazılmış (Hastaların yaşları, cinsiyetleri, geldikleri klinikler v.b.)ve aynı gün incelemeye alınmıştır. Direkt inceleme ve asit fast boyaması için gerekli işlemler bir taraftan yapılırken örneklerin bir bölümü DFA için \%10'luk formaline konmuştur.

Toplanan örneklerin incelenmesi: Tüm örneklere öncelikli olarak çoklaştırma yöntemleri uygulanarak;

1. Direkt inceleme: Lam lamel arası, serum fizyolojik ve lugol ile yapılmıştır.

2. Modifiye Asit Fast (MAF) boyama yöntemi için yayma preparatları hazırlanmış ve 100x lik objektifle Cryptosporidium spp. yönünden incelenmiştir.

3. DFA testi: Çalışmada immunofluoresan testi (MERIFLUOR ${ }^{\circledR} \mathrm{C} / \mathrm{G}$, Cincinati, Ohio USA) kullanılmıştır. Testler üretici firmanın önerdiği şekilde çalışılmış ve fluoresan mikroskobunda değerlendirilmiştir.

\section{Bulgular}

Gastroenterit yakınmalarıla başvuran 100 gastroenteritli hastanın 2'sinde direkt mikroskobide G. intestinalis görülmüştür. Aynı hastaların DFA testleri de pozitif saptanmiştır.

Asit-fast boyama ile hastaların birinde Cryptosporidium spp. görülürken, DFA ile 4'ünde $(\% 4,0)$ Cryptosporidium spp. antijenlerine rastlanmıştır (Tablo 1).

Tablo 1. İshalli hastalarda tanı için kullanılan yöntemler ve saptanan sonuçlar.

\begin{tabular}{|c|c|c|c|c|c|c|c|c|c|c|c|}
\hline \multirow{3}{*}{$\begin{array}{l}\text { Araştırılan } \\
\text { parazit }\end{array}$} & \multirow{3}{*}{$\begin{array}{l}\text { Araştırılan } \\
\text { grup }\end{array}$} & \multicolumn{10}{|c|}{ Araştırma yöntemi } \\
\hline & & \multicolumn{3}{|c|}{ Direkt mikroskobi } & \multicolumn{3}{|l|}{ Asit-fast } & \multicolumn{4}{|c|}{ DFA } \\
\hline & & $\begin{array}{l}+ \\
\text { Say1 (\%) }\end{array}$ & $\begin{array}{l}- \\
\text { Say1 }\end{array}$ & $(\%)$ & $\begin{array}{l}++ \\
\text { Say1 }(\%)\end{array}$ & - & $(\%)$ & $\begin{array}{l}+ \\
\mathrm{S}\end{array}$ & $(\%)$ & Say & $(\%)$ \\
\hline $\begin{array}{l}\text { Giardia } \\
\text { intestinalis }\end{array}$ & $\begin{array}{l}\text { Gastroenterit } \\
\mathrm{n}: 100\end{array}$ & 2,0 & 98 & 98,0 & GMD* & GM & & 2 & 2,0 & 98 & 98,0 \\
\hline $\begin{array}{l}\text { Cryptosporidium } \\
\text { spp. }\end{array}$ & $\begin{array}{l}\text { Gastroenterit } \\
\mathrm{n}: 100\end{array}$ & GMD & GM & & 1,0 & 99 & 99,0 & 4 & 4.0 & 96 & 96,0 \\
\hline
\end{tabular}

Her iki parazit birlikte aynı hastada saptanmamıştır. Bu nedenle her iki protozoon, 100 hastanın 6'sında saptanmıştır. Çalışmaya alınan 24 çocuk hasta Çocuk Sağlığı ve Hastalıkları Kliniği'nden, 66 erişkin hasta ise başta İç Hastalıkları Kliniği'nden olmak üzere İnfeksiyon, Gastrenteroloji, Nefroloji kliniklerinden gelmişlerdir. Çalışmada saptanan pozitifliklerin hepsinin 17 yaş ve üstü grupta saptanmış olması ilginç bulunmuştur. Çocuk hastaların hiç birinde herhangi bir paraziter etkene rastlanmamıştır.

Erişkin hasta grubunun 28'i kadın, 48'i ise erkek hastalardı. Kadın hastaların ikisinde DFA ile Cryptosporidium spp., erkek hastaların da ikisinde Cryptosporidium spp. ikisinde G.intestinalis saptanmıştır.

Çalışmada direkt mikroskobi incelemelerinde bir hastada Entamoeba histolytica trofozoitlerine rastlanmış ve antijen tarama testi(ELISA) ile sonuç doğrulanmıştır. Ayrıca 10 olguda Blastocystis hominis de direkt mikroskobik incelemelerde gözlenmiştir. 


\section{Tartışma}

İnsanda ilk cryptosporidiosis olgusu 1976 yılında bildirilmiştir. İlk yıllar özellikle immun sağlam bireylerde semptomsuz seyrettiği bildirilmişse de daha sonra yapılan çalışmalarla parazitin bu bireylerde de gastroenterit oluşturabildiği belirtilmiştir. Ancak immun sistemi bozuk bireylerde ölümcül olabilmesi bu bireylerdeki durum üzerine ilgiyi çekmiştir. Cryptosporidiosis AİDS hastalarında ağır seyretmekte olup, yaşamı tehdit edebilmekte, solunum sistemi, karaciğer, safra yolları gibi doku ve organlarda da parazit saptanabilmektedir [1-3].

Tzipori, bu parazitle ilgili yapmış olduğu deneysel çalışmalarla birçok hayvan ve insanı farklı izolatlarla enfekte edebilmiş, hatta insan ve hayvanlar arasında bazı geçişlerin olabileceğini saptamıştır [2].

Parazitin ookistlerinin normal su şebekelerinde kullanılan su dezenfeksiyonlarına karşı dirençli olduğu yapılan çalışmalarla gösterilmiştir. Klorlanan sulardan dahi bulaşma kapasitesi olan ookistlere bağlı olarak birçok su kaynaklı salgınlar da oluşmuştur. 1989 yılında İngilterede oluşan salgında 5000 kişi, 1993'te ABD'de çıkan salgında 400000 den fazla kişi Cryptosporidium spp.den etkilenmiştir. Amerika'da The Center for Disease Control and Prevention (CDC) 1993-1994'te oluşan su kaynaklı salgınların \%71inden Cryptosporidium spp. ve G.intestinalis 'in sorumlu olduğunu bildirmiştir [4, 5].

Parazitin konak hücreye yapışmasında; apikal bölgeden salınan reseptörlerin rolü olduğu düşünülmektedir. Başlıca reseptörler; GP900, GP40, Trap-C1, P23, Cpa135, CPS-500, CSL, CP12 ve CP2'dir. Parazit, konak hücre zarına yapıştıktan sonra oluşturulan parasitoforus vakuol içine yerleşmektedir. Bu özellik nedeniyle parazit hücre içinde ancak sitoplazma dışında yerleşmektedir.

Cryptosporidiosis'in prevalansı ülkenin gelişmişlik durumunda göre değişmektedir. Gelişmiş ülkelerdeki ishalli hastalarda ortalama \%2,2'lik bir oran, gelişmekte olan ülkelerdeki ishalli hastalarda ise ortalama \%6,1'lik bir oran bildirilmiştir [2].

Cryptosporidiosis'in ülkemizdeki yaygınlığına yönelik yapılan çalışmalarda farklı yöntemler kullanılarak; ishalli çocuklarda Elgün ve Koltaş [7] \%24,03; Özçelik ve ark. [10] \%11,8; Doğan ve Akgün [19] \%3,6; Aydın ve ark. [20] tarafından \% 20, Çeliksöz ve ark. [11] tarafindan \%19,8 oranında, Sönmez ve ark. [21] \%6,25; Y1lmaz ve ark. [8] $\% 4,9$ saptamışlardır. Bu çalışmalardan bazıları ELISA ve Asit-fast ile elde edilen sonuçlardır. DFA ile elde etmiş olduğumuz \%4'lük oran son iki çalışmaya yakın bulunmuştur. Yukarıdaki çalışmaların hiç birinde DFA kullanılmamıştır.

Cryptosporidiosis'in dünyadaki yaygınlığı, yapılan çalışmalardan bazılarında; Avrupa'da ve Amerika'da \%1-3, gelişmekte olan ülkelerde ise \%5-10 arasında değiştiği bildirilmiştir. Su kaynaklı salgınlar ise İngiltere ve Amerika Birleşik Devletlerinden bildirilmiş olup bunlardan 1993 te Milwaukee'de çıkan salgında 403000 kişinin C. hominis ile infekte olduğu saptanmıştır [4, 5].

Cryptosporidium tanısı için çeşitli testler geliştirilmiştir. Mikroskobi yöntemi bunların başında gelir. Dışkı veya dokulardan ookistleri ayırt edici boyama yöntemleri kullanılarak tanıya gidilebilir. Modifiye asid-fast boyama yöntemi bunlar içinde maliyeti ve yöntem kolaylığı nedeniyle en çok tercih edilendir ancak duyarlılığ oldukça düşüktür. Poliklonal ve monoklonal antikorların immun işaretlenmesiyle geliştirilen tanıda (DFA, ELISA. gibi) duyarlılık ve özgüllüğü oldukça yüksek ama daha pahalı tekniklerdir $[8,18,21,22]$.

Son dönemlerde tanıya eklenen PCR yöntemi ise çok daha duyarlı ve özgüldür. PCR amplifikasyon teknikleri, ookist duvar proteinleri, rRNA nın küçük alt ünitleri, beta tübilin, TRAP-C1, TRAP-C2, ITS1, Poly-T, DHFR veya unkown DNA ve mRNA parçacıklarından oluşturulan primerler kullanılarak tanı konulabilir [23].

Son yıllarda DFA yöntemi Cryptosporidium ookistlerinin aranmasında duyarlı ve özgül bir yöntem olduğu da belirlendiğinden sıklıkla kullanılmaktadır. Cryptosporidium için 
hazırlanan IFA ya da Direkt fluoresan antikor (DFA) kitleri günümüzde sıkça kullanılmakta olup bu kitler aynı zamanda Giardia intestinalis tanısını da yapabilecek şekilde piyasaya sunulmaktadır. Tanıda fluoresan mikroskobu altında ookistler karanlık zeminde parlak yeşil renkte görülmektedir. $\mathrm{Bu}$ yöntemle tür düzeyinde tanı konulamamaktadır [18].

Cryptosporidium'un serolojik testlerde kullanılan moleküler ağırlığı 15-17 kDa olan iki temel hedef antijeni bulunmaktadır. Bunlar Cp17 (gp15)ve $27 \mathrm{kDa}$ antijen olarak da bilinen Cp23 antijenleridir [16].

Giardia intestinalis ise, 1lıman bölgelerden tropikal kuşağa kadar insanlarda görülen önemli bir barsak protozoonudur. Birçok hastada asemptomatik görülmesine rağmen, kommensal olarak da adlandırılmamaktadır. Parazite kırsal bölgelerde iyi, yeterli ve dengeli beslenemeyen toplumlarda malnütrisyon ve malabsorpsiyon gibi çocuklarda çok ağır seyredebilen sorunlar oluşturabilmektedir. Sağlıklı görünen bireylerin bir kısmında yağlı dışkılamaya-steatorhe'ye yol açan G.intestinalis dünyada turist ishali olarak bilinen tablonun da bir üyesidir. Parazit insandan insana fekal oral yolla, kontamine su ve besin maddeleri ile olgun kist formunun ağızdan alınması ile oluşmaktadır. Gelişmekte olan ülkelerde ve Amerika dahil birçok gelişmiş ülkede endemik olduğu bilinmektedir. İlk kez Colorado'da bir salgından söz edilmekte ve lağım sularının içme sularına karışması nedeniyle $\% 23$ oranında $\mathrm{G}$. intestinalis'e rastlandığ 1 bildirilmiştir. Daha sonra Amerika'dan 95 salgın daha bildirilmiş ve bu salgınlardan 20 000'nin üzerinde insanın etkilendiği rapor edilmiştir [17].

Ülkemizde 1982-1996 yılları arasında yayınlanmış yayınların değerlendirilmesi ile hazırlanan bir çalışmada mikroskobik olarak araştırılan 316095 dışkı örneğinin 38 822'sinde $(\% 12,28)$ G.intestinalis görüldüğü belirtilmiştir. Yaş gruplarına göre değerlendirme yapıldığında $0-15$ yaş grubunda \%13,8; erişkin yaş grubunda ise \%11,2 oranında G. intestinalis saptanmış olduğu görülmektedir [24]. Bu bulgulardan aslında erişkin ve çocuk yaş gruplarındaki farkın önemli olmadığı görülmektedir. Ancak çalışmada hastalıkla ilgili bulgu ve klinik ile ilgili verilere yer verilmemiştir. Günümüzde bu oranların daha da azalmış olduğu son taramalarla da görülmektedir [18]. Bu nedenle çalışmış olduğumuz grupta görülen $\% 2$ oranı yine bölgemizde yapılan çalışmalarda saptanan genel sıklığı yansitmaktadır.

Çocuk yaş grubunda hiç rastlanmamış olması ve sadece iki hastada görülmüş olması incelediğimiz grupta ishal etkeni olarak bu parazitin sorumlu olamayacağı düşüncesini doğurmaktadır.

Giardiosisli hastalarda klinik olarak sıkça ishal, zaman zaman kabızlık görülür. Dışk1 gevşek ve sulu, nadiren kanlı ve zaman zaman da yă̆ içermektedir. Abdominal ağrı, bulantı, kusma, iştahsızlık, karında gaz, şişkinlik, yorgunluk hali gibi belirtiler görülebilmektedir. Laboratuvar tanısında etkensel tanının yanında indirekt tanı yöntemleri de kullanılabilmektedir [17, 25, 26]. İmmunodiagnostik amaçla kullanılan kitler, direkt fluoresan antikor testi (DFA), ELISA ve immünokromatografik dipstick testlerdir. Koproantijenik tanı yöntemleri kolay ve kısa zamanda sonuç veren testlerdir. Bu testlerin mikroskobi ile birlikte kullanılması önerilmektedir [27, 28].

Giardia'nın plazma membranı bütünüyle VSP(variant yüzey proten) ile kaplıdır. Hücre iskeletinde ise alfa-1 Giardin, 7,3 Giardin, Beta-Giardin ve beta-tubulin gibi çeşitli antijenik özellikteki proteinler bulunmaktadır. Bunlara karşı geliştirilen monoklonal antikorlar da antijen tarama testlerinde kullanılmaktadır [17].

Sonuç olarak; cryptosporidium spp. ve G. intestinalis 'in ikisini de içeren DFA testleri rutin çalışmalarda ve prevalans araştırmalarında kullanılabilen kolay, duyarlı ve güvenilir bir testtir. Diğer taraftan enterit nedenleri arasında sayılan bu iki protozoon bu olgularda bakteriyolojik ve viral etkenlerin yanında mutlaka araştırılmalıdır. 


\section{Kaynaklar}

1. Ramirez NE Ward LA, Sreevatsan S. A review of the biology and epidemiology of cryptosporidiosis in humans and animals. Microbes Infect 2004; 6: 773-85.

2. Tzipori S, Widmer G. A hundred year retrospective on cryptosporidiosis. Trends Parasitol 2008; 24: 184-9.

3. Mosier DA, Oberst RD. Cryptosporidiosis. A global challenge. Ann NY Acad. Sci 2000; 916: 102-11.

4. Richardson AJ, Frankenberg RA, Buck AC, Selcon JB, ColbourneJW, MayonWhite RT. An outbreak of waterborne cryptosporidiosis in Swindon and Oxfordshire. Epidemiol. Infect 1991; 107: 485-95.

5. Mac Kenzie WR, Hoxie NJ, Proctor ME, Gradus MS, Blair KA, Peterson DE, Kazmierczak JJ, Addiss DG, Fox KR, Rose JB. A massive outbreak in Milwaukee of Cryptosporidium infection transmittedthrough the publicwater supply. N Eng J Med 1994; 331: 161-7.

6. Çiçek M, Yılmaz H. İshalli çocuklarda Cryptosporidium spp. ve diğer barsak parazitlerinin yaygınlığı, Dicle Medical Journal 2011; 38: 70-5.

7. Elgun G, Koltas IS. Investigation of Cryptosporidium spp.antigen by ELISA method in stool specimens obtained from patients with diarrhea. Parasitol.Res 2011; 108: 395-7.

8. Yilmaz H, Tas Cengiz Z, Cicek M. Investigation of cryptosporidiosis by enzymelinked immunosorbent assay and microscopy in children with diarrhea. Saudi Med J 2008; 29: 526-59.

9. Ozcelik S, Poyraz Ö, Kalkan K, Malatyalı E, Degerli S. The investigation of Cryptosporidium spp. prevalence in cattle and farmers by ELISA. The Journal of the Faculty of Veterinary Medicine, University of Kafkas. SA 2012: 61-4.

10. Özçelik S, Dökmetaş S, Sümer Z, İçağasıoğlu D, Dökmetaş İ. Gastroenteritlilerde Cryptosporidium görülme sıklı̆̆ 1 Türk. Parazitol. Derg 1996; 20: 333-7.

11. Çeliksöz A, Çelik S.Cumhuriyet Üniversitesi Hastanesi'nde gastroenteritli ve malnütrisyonlu hastalarda Cryptosporidium spp. Araştırması. Türk Parazitol Derg 2003; 27: 85-8.

12. Graczyk TK, Kacprzak M, Neczaj E, Tamang L, Graczyk H, Lucy EF, Girouard AS. Occurrence of Cryptosporidium and Giardia in sewage sludge and solid waste landfill leachate and quantitative comparative analysis of sanitization treatments on pathogen inactivation. Environmental Research 2008; 106: 27-33.

13. LeChevalier, MW, Norton, WD, Lee, RG. Occurrence of Giardia and Cryptosporidium spp. in surface water supplies. Applied and Environmental Microbiology 1991; 57: 2610-6.

14. Lonigro A, Pollice A, Spinelli R, Berrilli F, Di Cave D, D'Orazi C, Cavallo P, Brandonisio O. Giardia cysts and Cryptosporidium oocysts in membrane-filtered municipal wastewater used for irrigation. Applied and Environmental Microbiology 2006; 72: 7916-78.

15. Madore, MS, Rose, JB, Gerba, CP., Arrowood, MJ, \& Sterling, CR. Occurrence of Cryptosporidium oocysts in sewage effluents and selected surface waters. Journal of Parasitology 1987; 73: 702-5.

16. Üner A, Tanrıverdi S, Caner A, Değirmenci A. Cryptosporidium'larda Moleküler Biyolojik Yapı ve Çalışmalar. Moleküler Parazitoloji içinde. Ed.Özcel MA, Tanyüksel M, Eren H. Türkiye Parazitoloji Derneği Yayını, Meta Basım, İzmir 2009; 22.

17. Ak M, Türk M, Güneş K. Giardiosis. Tıbbi Parazit Hastalıkları içinde. Ed: MA Özcel. Meta basım, İzmir 2007; 323-44.

18. Uyar Y, Özkan AT. Amebiyazis, giardiyazis ve kriptosporidiyazis tanısinda antijen tarama yöntemlerinin yeri. Türkiye Parazitoloji Derg 2009; 33: 140-50.

19. Doğan N, Akgün Y. İshalli olgularda Cryptosporidium ookistlerinin araştırılması. Türk. Parazitol.Derg 1998; 22: 243-6. 
20. Aydın F, Katırcıoğlu İ, Köseahmet F, Bakır T, Bingöl R. Kronik diyareli hastaların dışkı örneklerinde Kriptosporidiumun belirlenmesi. İnfeksiyon Derg. 1995; 9: 151-5.

21. Sönmez TG, Gülenç S. Diskida Cryptosporidium spp. antijenlerinin ELISA ile arastirilmasi. Türkiye Parazitol Derg 2008; 32: 198-201.

22. Graczyk TK, Cranfield MR, Fayer R. Evaluation of commercial enzyme immunoassay (EIA) and immunofluorescent antibody (FA) test kits fot detection of Cryptosporidium oocysts of species other than Cryptosporidium parvum. Am J Trop Med Hyg 1996; 54: 274-9.

23. Melrose W, Johnson K, Nimmo G. Use of multiplex real-time PCR to improve the detection of Giardia lamblia and Cryptosporidium parvum in human faecal samples. Amer.Soc. Trop. Med \& Hygiene 2007: 77: 76.

24. Özçelik S, Değerli S. Türkiye'de Giardiosis. T.Parazitol. Derg 1998; 22: 292-8.

25. Muhsen K, Levine MM. A systematic review and meta-analysis of the association between Giardia lamblia and endemic pediatric diarrhea in developing countries. Clin.Infect Dis 2012; 55: 271-93.

26. Veenemans J, Mank T, Ottenhof M, Baidjoe A, Mbugi E, Demir AY, Weilders JP, Savelkoul HF, Verhoef H. Protection against diarrhea associated with Giardia intestinalis is lost with multi-nutrient supplementation: A study in Tanzanian Children. PLoS Negl Trop Dis 2011; 5: 1158.

27. Doğruman Al F, Kuştimur S, Özekinci T, Balaban N, İlhan MN. The use of Enzyme Linked Immunosorbent Assay (ELISA) and Direct Fluoresan Antibody (DFA) methods for diagnosis of Giardia intestinalis. Acta Parasitologica Turcica 2006; 30: 275-8.

28. Weitzel T, Dittrch S, Möhl I, Adusu E, Jelinek T. Evaluation of seven commercial antigen detection tests for Giardia and Cryptosporidium in stool samples. Eur Soc Clin Micro İnf Dis 2006; 12: 656-9. 